\title{
ОСОБЛИВОСТІ ПРОЯВУ АДАПТИВНИХ ОЗНАК У СЕЛЕКЦІЙНИХ ПОПУЛЯЦІЙ ЛЮЦЕРНИ ПРИ ВИРОЩУВАННІ НА НАСІННЯ
}

\author{
Вожегова Раїса Анатоліївна \\ доктор сільськогосподарських наук, профресор, академік НААН України, директор \\ Інститут зрошуваного землеробства НААН України, м. Херсон, Україна \\ ORCID: 0000-0002-3895-5633 \\ Тищенко Андрій Вікторович \\ кандидат сільськогосподарських наук, старший науковий співробітник \\ Інститут зрошуваного землеробства НААН України, м. Херсон, Україна \\ ORCID: 0000-0003-1918-6223 \\ tischenko_andriy@ukr.net \\ Тищенко Олена Дмитрівна \\ кандидат сільськогосподарських наук, старший науковий співробітник \\ Інститут зрошуваного землеробства НААН України, м. Херсон, Україна \\ ORCID: 0000-0002-8095-9195 \\ elenat1946@ukr.net
}

Димов Олександр Миколайович кандидат сільськогосподарських наук, старший науковий співробітник Інститут зрошуваного землеробства НААН України, м. Херсон, Україна ORCID: 0000-0002-7839-0956

Люта Юлія Олександрівна кандидат сільськогосподарських наук, доцент ДВНЗ Приазовський державний технічний університет, м. Маріуполь, Україна yuliya.luta@gmail.com

Вивчено адаптивні ознаки у популяцій люцерни: пластичність, стабільність, генетичну гнучкість, загальну і специфрічну адаптивність при насіннєвому використанні, виділено перспективний матеріал для подальшого використання його у селекційному процесі. Дослідження проводились в Інституті зрошуваного землеробства НААН України протягом 2017-2020рр. Об'єктом вивчення слугували 24 популяції люцерни. Для оцінки умов вирощування використовували індекси умов середовища (lj). Найбільш сприятливі умови для фоормування насіннєвої продуктивності склалися у 2019 році (lj = +123,87), у 2017 році вони були несприятливими (lj = - 24,94), у 2018 році - дуже несприятливі (lj = - 98,93). Урожайність насіння у генотипів люцерни коливалась від 169,57 до 243,10 ке/га. Встановлено високий позитивний зв'язок урожайності насіння у популяцій люцерни (r=0,768-0,882) з показником генетичної гнучкості (Gf), загальної адаптивної здатності (OACi) ( $r=0,799-0,891)$ та коефріцієнтом адаптивності (KA) $(r=0,799-0,891)$. Аналізуючи отримані дані за насіннєвою продуктивністю, популяції люцерни першого року за параметрами адаптивної здатності та біплот-аналізом можна розділити на три групи: інтенсивного типу, стабільні та адаптовані до різних умов. До найкращих стабільних популяцій відносяться: М.g./ ЦП-11 і Ж./ ЦП-11, інтенсивного типу - LR/ H, Приморка / Сін(с) та адаптованих до різних умов - Син (c)./Приморка і А.-Н.d. № 15. Комплексна оцінка популяцій за врожайністю насіння люцерни і параметрам адаптивності з використанням різних методик і біплот-аналізу дозволила виділити генотипи, що мають високу потенційну продуктивність $і$ найбільшу адаптивність. До них відносяться генотипи: стабільні М.g./ЦП-11 і Ж./ ЦП-11, інтенсивного типу - LR/ H, Приморка / Сін(c) та адаптованих до різних умов - Син (c)./Приморка і А.-H.d. № 15, які доцільно використовувати у селекційному процесі люцерни на адаптивність при створенні нових сортів.

Ключові слова: генотип, насіннєва продуктивність, параметри адаптивних ознак, кореляція, біплот-аналіз.

DOI https://doi.org/10.32845/agrobio.2021.2.1

Вступ. Люцерна - багаторічна кормова культура, що вирощується в усьому світі, та серед кормових бобових культур характеризується високою продуктивністю біомаси, поживною цінністю з високим вмістом білка. Вона сприяє підвищенню родючості ґрунту (Latrach et al., 2014), захищає ґрунти від вітрової та водної ерозії (Abdelguerfi \& Abdelguerfi-Laouar, 2002). Крім того, фікса- ція атмосфрерного азоту робить її незамінним попередником для інших сільськогосподарських культур.

Згідно з численними прогнозами, глобальна зміна клімату призведе до підвищення температури, зміни географічної структури опадів і у майбутньому - до збільшення частоти екстремальних кліматичних явищ (Harrison, 2014). Пагубні наслідки абіотичного стресу $є$ серйозним обме- 
женням для вирощування цієї культури (Vasconcelos et al., 2008; Wang, 2015; Tyshchenko et al., 2021).

Одним із основних питань, що стоять перед селекціонерами люцерни, $є$ створення оптимального генотипу, здатного стабільно реалізовувати свій потенціал і при цьому реагувати на зміну умов вирощування. У зв'язку з цим, виникає потреба у різнобічній оцінці селекційного матеріалу за адаптивними ознаками і врожайністю у конкретних агроекологічних умовах. Крім того, для швидкого розмноження та впровадження у виробництво перспективних сортів люцерни вони повинні мати високу насіннєву продуктивність та бути адаптованими до різних умов вирощування.

За постійного впливу несприятливих чинників навколишнього середовища: температурні коливання, посухи, надмірне зволоження, засолення ґрунту тощо, кожен рослинний організм здатний адаптуватись до цих умов тільки у межах, обумовлених нормою реакції його генотипу. Чим вища здатність виду змінювати метаболізм, відповідно до діапазонів мінливих умов, тим ширша норма його реакції та вища еколого-адаптивна спроможність (Zajceva, 2015; Zhuchenko, 2009). Сьогодення вимагає ведення безперервного селекційного процесу з постійним його удосконаленням для забезпечення стабільності та зростання кормової і насіннєвої продуктивності культури, шляхом створення і впровадження нових сортів. На думку О. В. Кільчевського та Л. В. Хотильової саме адаптивна селекція забезпечує пристосувальні можливості сортів з максимальною і стабільною продуктивністю, поєднання продуктивності та стійкості до абіотичних, біотичних стресів в одному сорті та контроль екологічної стабільності (Kil'chevskij \& Hotyleva, 2008). Проте основне завдання сучасної селекції повинне бути спрямоване на створення сортів з підвищеною екологічною стійкістю, посиленням їх здатності забезпечувати високу та стабільну врожайність за різних умов вегетації (Goncharenko, 2016, a, b), тобто підтримувати високий рівень адаптації рослин до комплексу біотичних і абіотичних фракторів навколишнього середовища (Aseeva \& Zenkina, 2019).

За визначенням Лавриненка Ю. О. та ін. адаптивна селекція включає пластичність, стабільність у вузькому та широкому розумінні, тобто здатність генотипів зводити до мінімуму негативні наслідки впливу навколишнього середовища (Tyshchenko et al., 2021). На думку В. В. Базалія такі терміни, як стабільність, пластичність і гомеостатичність трактуються по-різному: іноді вони протиставляються один одному, або вважаються однозначними, а інколи доповнюють один одного (Bazalij, 2004). Пластичність і стабільність - це головні пристосувальні властивості рослин, що є відображенням модифікаційної мінливості під впливом фракторів довкілля. Пластичність ознак - це здатність генотипу змінюватись під впливом факторів середовища у межах, які контролюються самим генотипом (Orljuk \& Goncharova, 2002). Стабільність - це показник стійкості сорту в реалізації певного фенотипу в різних умовах середовища (Litun, 1980). Це дві протилежні сторони модифікаційної мінливості генотипу, тобто генотип не може бути одночасно стабільним і пластичним за досліджуваною ознакою (Giancarla et al.,
2010; Kil'chevskij \& Hotyleva, 2008). Як відзначають П. В. Поползухін разом із співавторами, пластичність, стабільність і гомеостатичність характеризують потенціал модифікаційної та генотипової мінливості окремих сортових ознак, головною з яких $€$ врожайність, а ступінь реакції генотипів на зміну умов середовища характеризує сорт за пластичністю, стабільністю і гомеостатичністю (Popolzuhin et al., 2018). Гомеостатичність - це показник, який об'єднує середню врожайність та адаптаційну норму реакції генотипів на лімітуючі фактори довкілля (Ashraf, 2010; Demidov et al., 2019). Із пластичністю тісно пов'язане поняття «екологічна стабільність», яка відображає здатність рослинних популяцій протистояти стресовим чинникам (Kordjum \& Dubina, 2015). На думку Л. П. Байкалової та Ю. І .Серебеннікова терміни «адаптивність», «екологічна пластичність», «екологічна стійкість» можуть замінюватися, а частіше доповнювати один одного (Bajkalova \& Serebennikov, 2014). Оцінка генотипів за цими показниками дозволяє виділити екологічно стійкі форми, які забезпечують стабільні врожаї в різних місцях вирощування. Тому однією з головних задач селекції $€$ підвищення адаптивного потенціалу сортів, тобто не тільки підвищення продуктивності рослин, але й поєднання її зі стійкістю до абіотичних і біотичних стресів (Ayalneh et al., 2013; Goncharenko, 2005; Mel'nik et al., 2020), що є критерієм адаптивної здатності рослин (Surin et al., 2016).

Мета досліджень - вивчення адаптивних ознак: пластичності, стабільності, генетичної гнучкості, загальної і специфічної адаптивності у селекційних популяцій люцерни при насіннєвому використанні, виділення перспективного матеріалу для подальшого використання у селекційному процесі.

Матеріали і методи досліджень. Дослідження проводили в Інституті зрошуваного землеробства НААН України (Україна, м. Херсон, сел. Наддніпрянське, 46²4'50.1"N $\left.32^{\circ} 42^{\prime} 30.0^{\prime \prime E}\right)$, що розташоване на Інгулецькому зрошуваному масиві, протягом 2017-2020 рр. у польових умовах. Об'єктом вивчення слугували сорти Унітро, Елегія, добори із селекційних зразків за потужністю кореневої системи, відібраних у заповіднику Асканія-Нова, сортів Rambler, Абайська різнокольорова, Сибірська 8 та гібридні популяції $\mathrm{F}_{3}-\mathrm{F}_{5}$, які були створені раніше. Оцінку проводили за насіннєвого використання в умовах природного зволоження. Площа ділянки 25,0 м². Статистичну обробку експериментальних даних проводили з використанням програм AgroSTAT, XLSTAT, Statistica (v. 13).

Для характеристики адаптивної здатності сорту в математичному вираженні у вітчизняній і зарубіжній літературі запропоновано ряд методів. Вони відрізняються за ступенем складності обчислень, інформативності, об'єктивності, роздільної здатності. Нами були обрані деякі з них для визначення адаптивних ознак. Індекс умов середовища (lj), коефіцієнт регресії (bi), екологічна стабільність, пластичність сорту в різних умовах середовища $\left(\mathrm{Si}^{2}\right)$, яку визначали за методикою S. A. Eberhart та W. A. Russell (Eberhart \& Russell, 1966), показник стресостійкості (Ymin - Ymax) і генетичної гнучкості ((Ymax + Ymin) / 2) - за рівняннями A. A. Rosielle та J. Hamblin у викладі А. А. Гон- 
чаренко (Goncharenko, 2016 a), параметри гомеостатичності (Hom) селекційної цінності (Sc) - за В. В. Хангільдіним та ін. (Hudzenko, 2019; Popov, 2019), коефріцієнт адаптивності (КА) - за методом Л. О. Животкова та ін. (Hudzenko, 2019), загальну адаптивну здатність (ОАСi), варіансу специфічної адаптивної здатності $\left(\sigma_{\text {сAсі }}^{2}\right)$, відносну стабільність генотипу $\left(\mathrm{s}_{\mathrm{gi}}\right)$, селекційну цінність генотипу (СЦГі), коефіцієнти нелінійності (Igi) і компенсаціїдестабілізації (Kgi) визначали за О. В. Кільчевським та Л. В. Хотильовою (Kil'chevskij \& Hotyleva, 1985). Метеорологічні умови у роки проведення досліджень суттєво різнилися як за кількістю опадів і сумою температур, так і за характером їх розподілу протягом вегетаційного періоду. Це дозволило більш повно оцінити потенціал генотипів люцерни і виділити кращі з них за продуктивністю і стійкістю до несприятливих факторів.

Результати. Умови вирощування люцерни першого року життя травостою у роки досліджень суттєво різнилися. Для їх оцінки використовували індекси умов середовища (lj). Кращі умови для росту і розвитку рослин складаються при позитивному значенні умов середовища, гірші - при негативному. 3 аналізу індексів умов середовища випливає, що найбільш сприятливі умови для формування насіннєвої продуктивності склалися у 2019 році (lj = + 123,87), у 2017 році вони були несприятливими ( $\mathrm{lj}=-24,94)$, у 2018 році умови для формування врожайності були дуже несприятливими (lj = - 98,93).

За роки досліджень урожайність насіння у генотипів люцерни коливалась у широких межах: від 169,57 до 243,10 кг/га при коефіцієнті варіювання $V=11,03$ \%. Найбільша середня врожайність (Ymean) відзначена у генотипів: А.-H.d. № 15 (226,30 кг/га), М.g./ П.п. (227,67), Син (с)./ Приморка $(229,87)$ та M.g./ЦП-11 (243,10 кг/га) (табл. 1).

Стійкість до стресу популяцій - важливий показник адаптивності й екологічної пластичності, який визначається різницею між мінімальною і максимальною врожайністю (Ymin - Ymax). Цей параметр має негативний знак, і чим більша величина цього показника, тим вища стійкість генотипів до несприятливих факторів середовища (Goncharenko, 2016 a). Показник стресостійкості

Таблиця 1

Гомеостатичність і адаптивність популяцій люцерни першого року життя за ознакою врожайності насіння (2017-2019 рр.)

\begin{tabular}{|c|c|c|c|c|c|c|c|c|c|c|c|}
\hline \multirow{2}{*}{ Сорт, популяція } & \multirow{2}{*}{ 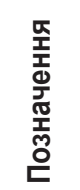 } & \multicolumn{3}{|c|}{ 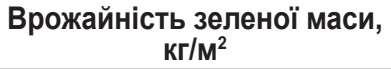 } & \multicolumn{7}{|c|}{ Параметри адаптивності } \\
\hline & & Ymin & Ymax & Ymean & $\begin{array}{l}Y \min - \\
Y \max \end{array}$ & Sc & Gf & bi & $\mathrm{Si}^{2}$ & KA & Hom \\
\hline Унітро, ст.-т & G1 & 83,3 & 269,0 & 169,5 & $-112,7$ & 98,5 & 213 & 0,82 & 82,5 & 86,5 & 46,3 \\
\hline Елегія & G2 & 95,2 & 300,0 & 191,3 & $-121,4$ & 113,9 & 239 & 0,90 & 152,2 & 97,5 & 54,7 \\
\hline Приморка & G3 & 107,1 & 300,0 & 196,0 & $-119,1$ & 118,2 & 241 & 0,86 & 61,0 & 99,9 & 58,5 \\
\hline М.g./ П.п. & G4 & 107,1 & 395,0 & 227,7 & $-214,1$ & 104,3 & 288 & 1,31 & 305,5 & 116,1 & 43,9 \\
\hline Син (с)./Приморка & G5 & 118,6 & 376,2 & 229,9 & $-181,4$ & 119,0 & 286 & 1,17 & 56,1 & 117,2 & 52,9 \\
\hline $\mathrm{LR} / \mathrm{H}$ & G6 & 71,4 & 324,3 & 176,5 & $-190,4$ & 72,9 & 229 & 1,16 & 296,5 & 90,0 & 29,7 \\
\hline Приморка / Сін(с) & G7 & 71,4 & 321,4 & 175,6 & $-187,5$ & 73,1 & 228 & 1,14 & 270,6 & 89,5 & 29,8 \\
\hline A.-H. d. № 114 & G8 & 83,3 & 333,3 & 191,0 & $-177,0$ & 89,6 & 245 & 1,13 & 64,5 & 97,4 & 37,4 \\
\hline A.-H.d. № 15 & G9 & 131,0 & 352,4 & 226,3 & $-156,9$ & 125,5 & 274 & 1,00 & 52,3 & 115,4 & 59,2 \\
\hline A.-H. d. № 38 & G10 & 119,0 & 339,0 & 210,4 & $-165,8$ & 107,5 & 256 & 1,01 & 228,5 & 107,3 & 48,5 \\
\hline Добір за к.с. & G11 & 71,4 & 304,8 & 170,0 & $-170,9$ & 74,7 & 219 & 1,06 & 144,7 & 86,7 & 30,7 \\
\hline Ram. d. & $\mathrm{G} 12$ & 83,8 & 297,6 & 175,3 & $-153,0$ & 85,2 & 221 & 0,97 & 66,8 & 89,4 & 36,5 \\
\hline$(\text { Емерауде /T. })^{2}$ & G13 & 71,4 & 304,8 & 170,0 & $-170,9$ & 74,7 & 219 & 1,06 & 144,7 & 86,7 & 30,7 \\
\hline Т./Емерауде & G14 & 119,0 & 309,5 & 210,6 & $-106,3$ & 138,3 & 256 & 0,83 & 281,7 & 107,4 & 75,7 \\
\hline M.g./ЦПП-11 & G15 & 154,8 & 364,3 & 243,1 & $-154,1$ & 140,3 & 287 & 0,95 & 129,0 & 124,0 & 69,6 \\
\hline Зимостійка/М.К. & G16 & 95,2 & 309,5 & 194,4 & $-130,9$ & 112,2 & 244 & 0,95 & 96,2 & 99,2 & 52,4 \\
\hline M.agr/C. & G17 & 77,6 & 328,6 & 198,5 & $-139,3$ & 114,4 & 259 & 1,10 & 516,3 & 101,2 & 51,3 \\
\hline A.r. d. & G18 & 75,7 & 269,0 & 170,6 & $-102,0$ & 105,9 & 218 & 0,84 & 472,2 & 87,0 & 51,8 \\
\hline M.g./ M.agr. & G19 & 85,7 & 333,3 & 195,3 & $-166,3$ & 97,9 & 250 & 1,11 & 0,6 & 99,6 & 41,6 \\
\hline M.g. d. & G20 & 95,2 & 333,3 & 202,4 & $-154,7$ & 108,4 & 256 & 1,06 & 12,1 & 103,2 & 48,0 \\
\hline$\Phi \mathrm{XHB}^{2}$ & G21 & 85,7 & 297,6 & 183,4 & $-130,6$ & 102,9 & 232 & 0,94 & 76,8 & 93,5 & 46,8 \\
\hline В.11/П. d. & G22 & 119,0 & 345,2 & 219,1 & $-152,0$ & 122,6 & 269 & 1,02 & 0,5 & 111,7 & 57,3 \\
\hline Ж./ ЦП-11 & G23 & 117,1 & 285,7 & 201,2 & $-84,8$ & 141,5 & 243 & 0,73 & 497,0 & 102,6 & 86,7 \\
\hline Сибір. 8, d.. & G24 & 93,3 & 285,7 & 178,4 & $-129,4$ & 97,6 & 221 & 0,86 & 0,5 & 91,0 & 44,7 \\
\hline $\mathrm{V}, \%$ & & 22,81 & 9,98 & 11,03 & $-21,35$ & 19,39 & 9,41 & 13,83 & 94,66 & 11,02 & 28,97 \\
\hline$S \dot{x}_{a \sigma c}$ & & 4,53 & 6,52 & 4,41 & 6,49 & 4,19 & 4,72 & 0,03 & 32,27 & 2,25 & 2,92 \\
\hline$S \dot{x}_{\text {віднос. }}$ & & 4,66 & 2,04 & 2,25 & $-4,36$ & 3,96 & 1,92 & 2,82 & 19,32 & 2,25 & 5,91 \\
\hline $\mathrm{HIP}_{01}$ & & 14,34 & 20,67 & 13,99 & 20,56 & 13,27 & 14,96 & 0,09 & 102,31 & 7,13 & 9,25 \\
\hline $\mathrm{HIP}_{05}$ & & 10,36 & 14,93 & 10,11 & 14,85 & 9,59 & 10,81 & 0,07 & 73,91 & 5,15 & 6,69 \\
\hline
\end{tabular}


серед досліджуваних генотипів люцерни коливався від - 84,80 до - 214,10. Найбільш високу стійкість до стресів проявила популяція Ж./ ЦП-11 - ((Ymin - Ymax) 84,80 кг/га), найменшу - M.g./ П.п. з показником ((Ymin$Y \max )=-214,10)$.

За допомогою індексу селекційної цінності (Sc) можна виділити генотипи, що поєднують високу або середню урожайність 3 її стабільною реалізацією у мінливих умовах вирощування. Вона визначає добуток середньої врожайності до відношення між мінімальною та максимальною врожайністю за роки досліджень (Ymean × (Ymin / Ymax)). Результати оцінки показали широкий діапазон варіювання за цим показником: від 72,89 до 141,50. Серед досліджуваних генотипів високі значення селекційної цінності показали популяції: Т./Емерауде; M.g./ЦП-11 та Ж./ ЦП-11 зі значеннями 138,25, 140,27, 141,50 відповідно. Аналіз мінливості врожайності насіння у популяцій люцерни показує, що лімітуючим фактором врожайності $€$ його стійкість до несприятливих факторів зовнішнього середовища, тобто його буферність або гомеостатичність. Найбільша величина гомеостатичності спостерігається у цих популяцій з числовими значеннями Hom = 75,70; 69,60 та 86,67 відповідно, тобто ці генотипи можуть свої генетичні можливості реалізувати при зміні умов вирощування. Як вказує В. В. Хангільдін (Popov et al., 2019), генотипи з високим гомеостазом (Hom) і високим показником селекційної цінності (Sc) слабкіше реагують на погіршення умов і добре відгукуються на їх поліпшення.

Характеристику популяцій до стресу доповнює показник генетичної гнучкості (Gf) або його компенсаторної здатності, що відображає середню врожайність сортів у контрастних (оптимальних і лімітуючих) умовах. Високі значення цього показника вказують на великий ступінь відповідності між генотипом популяції і факторами середовища. Вищий показник за генетичною гнучкістю (Gf) у контрастних умовах спостерігали у популяцій люцерни: М.g./ П.п. - 287,95, Син (с)./Приморка - 285,50 та 287,25 у М.g./ЦП-11, при значенні $\mathrm{Gf}=212,65$ у стандартного сорту Унітро.

Про адаптивність генотипів до умов середовища судять також за екологічною пластичністю та стабільністю їх урожайності. Пластичність оцінюється за коефіцієнтом регресії (bi), який є критерієм (індексом) оцінки рівня екологічної пластичності і вказує на реакцію генотипу на зміну умов середовища. Чим більший bi, тим сорт більш чутливий до зміни умов вирощування. У разі якщо bі нульовий або прагне до нуля, то сорт не реагує на зміну умов середовища. Якщо bі дорівнює або близький до одиниці, зміна врожайності повністю відповідає зміні умов вирощування. Про стабільність судять за варіансою стабільності $\left(\mathrm{Si}^{2}\right)$, розрахованою за дисперсією відхилень фактичних врожаїв від теоретично очікуваних. I чим вона менша, тим більшу стабільність мають генотипи, тобто низькі значення $\mathrm{Si}^{2}$ показують, що популяція слабо відгукується на поліпшення умов вирощування та на скільки $\mathrm{Si}^{2}$ відповідає пластичності за оцінкою коефіцієнта регресії.

Аналіз результатів досліджень показав, що популяції M.g./ П.п, Син (c)./Приморка, LR/ H, Приморка / Сін(c), А.-H. d. № 114 мали значення bi > 1 з варіюванням від 1,13 до 1,31 та які можна віднести до високо пластичних, що дуже реагують на зміну умов середовища. До цієї групи належать генотипи M.g./ M.agr., В.11/П. d., але з меншими значеннями коефіцієнта регресії bi = 1,02-1,11. Популяція А.-H. d. № 15 з показником коеффіцієнта регреciï bi $=1,00 €$ добре адаптованою до різноманітних умов середовища вирощування.

Аналізуючи інші показники (пластичність та стабільність) цих популяцій, можна сказати, що генотип Ж./ ЦП-11 характеризується найнижчим показником пластичності (bi $=0,73$ ), що вказує на її стабільність, однак високий коефіцієнт стабільності $\left(\mathrm{Si}^{2}=496,96\right)$ говорить про протилежне. У популяції M.g./ П.п. високі значення коефіцієнтів регресії (bi = 1,31), що означає високу її пластичність, а високий коефіцієнт стабільності $\left(\mathrm{Si}^{2}=305,51\right)$ підтверджує це. Тому для відбору конкурентоспроможних генотипів доцільно характеризувати їх за комплексом адаптивних ознак.

Значні відмінності спостерігалися за параметром стабільності $\left(\mathrm{Si}^{2}\right)$ урожайності серед досліджуваних генотипів з діапазоном варіювання від 0,51 до 496,6, й популяції з найнижчими значеннями цієї ознаки можуть вважатися найбільш стабільними. Кращими були популяції: M.g./ M.agr. - 0,55, В.11/П. d. - 0,54 та Сибір. 8, d. - 0,51. Але перші дві з них мають коефіцієнт регресії bi > 1, що $€$ нетиповим для стабільних популяцій. I тільки, генотип Сибір. 8, d. має показник коефіцієнта регресії bi < $1(0,86)$, що характеризує її як стабільну. Аналіз отриманих даних показав, що поєднання високої пластичності та стабільності врожайності відмічено тільки у двох популяцій: M.g./ M.agr. (bi =1,11, Si²=0,55), B.11/П. d. (bi =1,02, $\left.\mathrm{Si}^{2}=0,54\right)$.

Для оцінки продуктивного і адаптивного потенціалу генотипів люцерни використовували коефіцієнт адаптивності (КА) за Л. О. Животковим (Hudzenko, 2019), який відображає відношення середньої врожайності популяції до «середньопопуляційної врожайності». Це зіставлення врожайності досліджуваних генотипів проводиться не зі стандартом, а з середньою врожайністю за всіма порівнюваними популяціями. Показник норми реакції їх у кожному році приймається за 100 \%. Реакцію ж окремого генотипу на сформовані конкретні умови вегетаційного періоду можна визначити за співвідношення його врожайності до «середньопопуляційної». При цьому цифрове значення цього показника може виражатися як відносна величина. Якщо КА перевищує $100 \%$, то такий генотип $€$ потенційно високо продуктивним. Максимальними значеннями коефіцієнта адаптивності характеризувалися популяції: М.g./ЦП-11, Син (с)./ Приморка та M.g./ П.п. й А.-H.d. № 15 з показниками КА $=123,96 ; 117,21 ; 116,06$ і 115,40 відповідно. Коефіцієнт адаптивності у стандартного сорту Унітро був одним 3 найнижчих та становив 86,45.

Кореляційним аналізом отриманих даних за роки досліджень встановлено високий позитивний зв'язок урожайності насіння у популяцій люцерни $(r=0,768-0,882)$ з показником генетичної гнучкості (Gf) та коефіцієнтом адаптивності (КА) ( $r=0,799-0,891)$. В роки з гіршими умовами (2017 і 2018 рр.) врожайність насіння мала високу кореляційну залежність із селекційною цінністю 
(Sc) $(r=0,834-0,976)$ та гомеостатичністю (Hom) $(r=0,750-0,890)$, тоді як за кращих умов (2019 р.) вона була низькою. Коефіцієнт регресії мав високий зв'язок (bi) $(r=0,746)$ з врожайністю в кращих умовах, тоді як 3 врожайністю в гірших він був від'ємним і низьким $(r=-0,200-0,264)$. Дослідження кореляційних залежностей дозволяє визначити ті ознаки, які можуть бути фракторіальними і слугувати критеріями для відбору на продуктивність з урахуванням стійкості до абіотичних факторів. Ці ознаки визначені (Gf, KA, Sc, Hom, bi) і вони дозволять вести селекцію більш цілеспрямовано (табл. 2).

За комплексом ознак гомеостатичністі та показниками адаптивності найбільш стабільною виявилася популяція Ж./ ЦП-11, яка перевищувала стандарт за врожайністю. Вона характеризувалася високою гомеостатичністю (Hom = 86,67), селекційною цінністю (Sc = 141,50), коефіцієнтом адаптивності (КА = 102,61), а показник пластичності був меншим за одиницю (bi $=0,73)$, проте показник стабільності був найвищим $\mathrm{Si}^{2}=496,96$.

Генотип M.g./ П.п. перевищував стандарт за врожайністю, володів високими коефіцієнтами регресії bi = 1,31 і стабільності $-\mathrm{Si}^{2}=305,51$, та характеризувався високим коефіцієнтом адаптивності - КА = 116,09. За даними показниками цю популяцію можна віднести до інтенсивного типу. Популяція А.-H.d. № 15 добре адаптована до різноманітних умов середовища вирощування (bi = 1) та перевищувала стандарт за врожайністю.

Для більш повного аналізу адаптивної здатності популяцій люцерни за методикою О. В. Кільчевського та Л. В. Хотильової (Kil'chevskij \& Hotyleva, 1985) були розраховані параметри адаптивності: загальна адаптивна здатність (ОАСі), показник взаємодії генотип-середовище $\left(\sigma_{(G \times E) g i}^{2}\right)$, варіанса специфрічної адаптивної здатності $\left(\sigma_{\text {сасі }}^{2}\right)$, відносна стабільність генотипу $\left(\mathrm{s}_{\mathrm{gi}}\right)$, селекційна цінність генотипу (СЦГі), коефіцієнт компенсації-дестабілізації $\left(\mathrm{K}_{\mathrm{gi}}\right)$, коефріцієнт нелінійності $\left(\mathrm{I}_{\mathrm{gi}}\right)$ та реакції популяцій на середовище. На думку О. В. Кільчевського та та Л. В. Хотильової під адаптивною здатністю розуміють властивість популяції підтримувати характерну для неї величину фенотипового прояву ознаки. При цьому розрізняють загальну та специфічну адаптивність (Kil'chevskij \& Hotyleva, 1985).

Загальна адаптивна здатність (ОАСі) коливається у широких межах, від - 0,11 до 46,99, та характеризує відхилення середньосортового значення по роках досліджень від средньопопуляційной. За показником врожайності насіння високим значенням ОАСі була відмічена популяція M.g./ЦП-11 - 46,99. Дещо нижчими значеннями $(31,56$ й 33,76) характеризувалися генотипи: M.g./ П.п. і Син (с)./Приморка (табл. 3).

Варіанса специфічної адаптивної здатності $\left(\sigma_{\text {CAсі }}^{2}\right)$ показує стабільність популяції і $є$ більш інфрормативною, порівняно з показником взаємодії «популяція-середовище» $\left(\sigma_{(G \times E) g)}^{2}\right)$, тому що враховує компенсаційний ефрект. Широкий діапазон варіювання спостерігався у показника варіанси специфічної адаптивної здатності $\left(\sigma_{\text {сасі }}^{2}\right)$ від 6942 до 22197. Меншим значенням цього показника, а й відповідно високою стабільністю відрізнявся генотип Ж./ ЦП-11 зі значенням 6942. Дещо вищі показники мали: стандартний сорт Унітро - 8587, популяції Т./Емерауде 8948, A.r. d. - 9186, Приморка - 9309 та Сибір. 8, d. - 9457.

Параметр відносної стабільності генотипу $\left(\mathrm{s}_{\mathrm{gi}}\right)$ не пов'язаний із загальною адаптивною здатністю та носить відносний характер. Багато дослідників вказують на спадковий характер даного показника, що дозволяє використовувати генотипи в селекції на стабільність. На підставі отриманих результатів можна відзначити, що за параметром відносної стабільності генотипу $\left(\mathrm{s}_{\mathrm{gi}}\right)$ найнижчими характеризувалися селекційні номери: Ж./ ЦП-11 41,4, M.g./ЦП-11 - 44,3 та 44,9 у популяції Т./Емерауде.

Високими показниками селекційної цінності СЦГі серед досліджуваних популяцій, виділялися: А.-H.d. № 15 зі значенням 129,1, Т./Емерауде - 129,3 та Ж./ ЦП-11 129,6 , але найвищим - 150,5 характеризувалася популяція М.g./ЦП-11.

Селекційні номери мали лінійну реакцію на умови зовнішнього середовища $\left(\mathrm{I}_{\mathrm{gi}}=-0,0118-0,1484\right)$. Варіювання коефіцієнта компенсації-дестабілізації становило 0,55-1,75, що вказує як на компенсуючі, так і дестабілізуючі ефекти.

Таблиця 2

Кореляційні залежності між врожайністю насіння популяцій люцерни першого року життя та гомеостатичністю і параметрами адаптивності (2017-2019рр.)

\begin{tabular}{|c|c|c|c|c|c|c|c|c|c|c|c|}
\hline & Y17/17 & Y18/18 & Y19/19 & Ymean & $\begin{array}{c}\text { Ymin- } \\
\text { Ymax }\end{array}$ & $\mathbf{S c}$ & $\mathbf{G f}$ & $\mathbf{b i}$ & $\mathbf{S i}^{2}$ & $\mathbf{K A}$ & $\mathbf{H o m}^{2}$ \\
\hline Y17/17 & 1,000 & 0,837 & 0,375 & 0,834 & 0,363 & 0,976 & 0,768 & $-0,264$ & 0,100 & 0,834 & 0,890 \\
\hline Y18/18 & 0,837 & 1,000 & 0,498 & 0,891 & 0,119 & 0,834 & 0,770 & $-0,200$ & $-0,144$ & 0,891 & 0,750 \\
\hline Y19/19 & 0,375 & 0,498 & 1,000 & 0,799 & $-0,727$ & 0,194 & 0,882 & 0,746 & $-0,139$ & 0,799 & 0,005 \\
\hline Ymean & 0,834 & 0,891 & 0,799 & 1,000 & $-0,185$ & 0,735 & 0,976 & 0,203 & $-0,081$ & 1,000 & 0,581 \\
\hline $\begin{array}{c}\text { Ymin }- \\
\text { Ymax }\end{array}$ & 0,363 & 0,119 & $-0,727$ & $-0,185$ & 1,000 & 0,527 & $-0,317$ & $-0,945$ & 0,214 & $-0,185$ & 0,654 \\
\hline Sc & 0,976 & 0,834 & 0,194 & 0,735 & 0,527 & 1,000 & 0,631 & $-0,459$ & 0,125 & 0,735 & 0,962 \\
\hline Gf & 0,768 & 0,770 & 0,882 & 0,976 & $-0,317$ & 0,631 & 1,000 & 0,381 & $-0,045$ & 0,976 & 0,456 \\
\hline bi & $-0,264$ & $-0,200$ & 0,746 & 0,203 & $-0,945$ & $-0,459$ & 0,381 & 1,000 & $-0,081$ & 0,203 & $-0,605$ \\
\hline Si2 & 0,100 & $-0,144$ & $-0,139$ & $-0,081$ & 0,214 & 0,125 & $-0,045$ & $-0,081$ & 1,000 & $-0,081$ & 0,243 \\
\hline KA & 0,834 & 0,891 & 0,799 & 1,000 & $-0,185$ & 0,735 & 0,976 & 0,203 & $-0,081$ & 1,000 & 0,581 \\
\hline Hom & 0,890 & 0,750 & 0,005 & 0,581 & 0,654 & 0,962 & 0,456 & $-0,605$ & 0,243 & 0,581 & 1,000 \\
\hline
\end{tabular}

Примітка: Y17/17 - сівба 2017 р. - врожайність 2017 р., Y18/18 - сівба 2018 р. - врожайність 2018 p., Y19/19 - сівба 2019 p. врожайність 2019 р. 
Параметри адаптивних властивостей зразків люцерни першого року життя за ознакою врожайності насіння за методикою О. В. Кільчевського та Л. В. Хотильової (2017-2019рр.)

\begin{tabular}{|c|c|c|c|c|c|c|c|c|c|c|c|}
\hline \multirow[b]{2}{*}{ Сорт, популяція } & \multirow{2}{*}{ 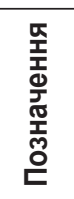 } & \multirow[b]{2}{*}{ Ymin } & \multicolumn{2}{|c|}{$\begin{array}{c}\text { Врожайність } \\
\text { зеленої маси, кг/м² }\end{array}$} & \multicolumn{7}{|c|}{ Параметри адаптивності } \\
\hline & & & $Y \max$ & Ymean & ষ্তু & 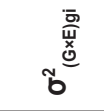 & $\boldsymbol{\sigma}_{\mathrm{CACi}}^{2}$ & $\mathbf{s}_{\mathrm{gi}}$ & СцГі & $\mathrm{K}_{\mathrm{gi}}$ & $\mathrm{I}_{\mathrm{gi}}$ \\
\hline Унітро, ст.-Т & G1 & 83,3 & 269,0 & 169,5 & $-26,6$ & 289 & 8587 & 54,7 & 89,9 & 0,68 & 0,0336 \\
\hline Елегія & G2 & 95,2 & 300,0 & 191,3 & $-4,8$ & 36 & 10441 & 53,4 & 103,4 & 0,82 & 0,0034 \\
\hline Приморка & G3 & 107,1 & 300,0 & 196,0 & $-0,1$ & 138 & 9309 & 49,2 & 113,1 & 0,73 & 0,0148 \\
\hline М.g./ П.п. & G4 & 107,1 & 395,0 & 227,7 & 31,6 & 1259 & 22197 & 65,4 & 99,6 & 1,75 & 0,0567 \\
\hline Син (с)./Приморка & G5 & 118,6 & 376,2 & 229,9 & 33,8 & 222 & 17347 & 57,3 & 116,7 & 1,36 & 0,0128 \\
\hline LR/H & G6 & 71,4 & 324,3 & 176,5 & $-19,6$ & 303 & 17188 & 74,3 & 63,9 & 1,35 & 0,0176 \\
\hline Приморка / Сін(с) & G7 & 71,4 & 321,4 & 175,6 & $-20,5$ & 237 & 16762 & 73,7 & 64,3 & 1,32 & 0,0141 \\
\hline A.-H. d. № 114 & G8 & 83,3 & 333,3 & 191,0 & $-5,1$ & 98 & 1636 & 67,0 & 81,0 & 1,29 & 0,0060 \\
\hline A.-H.d. № 15 & G9 & 131,0 & 352,4 & 226,3 & 30,2 & -132 & 12801 & 50,0 & 129,1 & 1,01 & $-0,0103$ \\
\hline A.-H. d. № 38 & G10 & 119,0 & 339,0 & 210,4 & 14,3 & -44 & 12973 & 54,1 & 112,5 & 1,02 & $-0,0034$ \\
\hline Добір за к.с. & G11 & 71,4 & 304,8 & 170,0 & $-26,1$ & -36 & 14433 & 70,7 & 66,8 & 1,14 & $-0,0025$ \\
\hline Ram. d. & $\mathrm{G} 12$ & 83,8 & 297,6 & 175,3 & $-20,8$ & -113 & 11971 & 62,4 & 81,3 & 0,94 & $-0,0094$ \\
\hline$(\text { Емерауде /Т. })^{2}$ & $\mathrm{G} 13$ & 71,4 & 304,8 & 170,0 & $-26,1$ & -36 & 14433 & 70,7 & 66,8 & 1,14 & $-0,0025$ \\
\hline Т./Емерауде & G14 & 119,0 & 309,5 & 210,6 & 14,5 & 334 & 8948 & 44,9 & 129,3 & 0,70 & 0,0374 \\
\hline М.g./ЦП-11 & G15 & 154,8 & 364,3 & 243,1 & 47,0 & -67 & 11619 & 44,3 & 150,5 & 0,91 & $-0,0057$ \\
\hline Зимостійка/М.К. & G16 & 95,2 & 309,5 & 194,4 & $-1,7$ & -78 & 11504 & 55,2 & 102,3 & 0,91 & $-0,0068$ \\
\hline M.agr/C. & G17 & 77,6 & 328,6 & 198,5 & 2,4 & 227 & 15649 & 63,0 & 91,0 & 1,23 & 0,0145 \\
\hline A.r. d. & G18 & 75,7 & 269,0 & 170,6 & $-25,5$ & 402 & 9186 & 56,2 & 88,2 & 0,72 & 0,0438 \\
\hline M.g./ M.agr. & G19 & 85,7 & 333,3 & 195,3 & $-0,8$ & 4 & 15764 & 64,3 & 87,4 & 1,24 & 0,0003 \\
\hline M.g. d. & $\mathrm{G} 20$ & 95,2 & 333,3 & 202,4 & 6,3 & -99 & 14432 & 59,4 & 99,1 & 1,14 & $-0,0068$ \\
\hline$\Phi \mathrm{XHB}^{2}$ & G21 & 85,7 & 297,6 & 183,4 & $-12,7$ & -74 & 11263 & 57,9 & 92,2 & 0,89 & $-0,0066$ \\
\hline B.11/П. d. & G22 & 119,0 & 345,2 & 219,1 & 23,0 & -155 & 13131 & 52,3 & 120,7 & 1,03 & $-0,0118$ \\
\hline Ж./ ЦП-11 & G23 & 117,1 & 285,7 & 201,2 & 5,1 & 1030 & 6942 & 41,4 & 129,6 & 0,55 & 0,1484 \\
\hline Сибір. 8, d.. & G24 & 93,3 & 285,7 & 178,4 & $-17,7$ & 79 & 9457 & 54,5 & 94,9 & 0,74 & 0,0083 \\
\hline $\mathrm{V}, \%$ & & 22,81 & 9,98 & 11,03 & - & 217,49 & 27,51 & 13,81 & 15,75 & 23,30 & 27,54 \\
\hline$S \dot{x}_{\text {afc }}$ & & 4,53 & 6,52 & 4,44 & 4,41 & 70,73 & 731,54 & 3,19 & 1,87 & 4,70 & 0,06 \\
\hline$S \dot{X}_{\text {sinte }}$ & & 4,66 & 2,04 & 2,25 & - & 44,40 & 5,62 & 2,82 & 3,22 & 4,76 & 5,62 \\
\hline $\mathrm{HIP}_{01}$ & & 14,34 & 20,67 & 13,99 & 13,99 & 224,22 & 2318,98 & 10,11 & 5,93 & 14,91 & 0,18 \\
\hline $\mathrm{HIP}_{05}$ & & 10,36 & 14,93 & 10,11 & 10,11 & 161,98 & 1675,22 & 7,30 & 4,28 & 10,77 & 0,13 \\
\hline
\end{tabular}

Насіннєва продуктивність популяцій люцерни за роки досліджень має високий позитивний кореляційний зв'язок $(r=0,799-0,891)$ з показником загальної адаптивної здатності (ОАСi). В роки 3 гіршими умовами (2017 і 2018 рр.) врожайність насіння мала високу позитивну кореляційну залежність з селекційною цінністю генотипу (СЦГі) ( $r=0,935-0,955)$ та високу від'ємну з показником відносної стабільності $\left(\mathrm{s}_{\mathrm{gi}}\right)(\mathrm{r}=-0,777--0,819)$, тоді як за кращих умов $(2019$ р.) вона була середньою $(r=0,316)$ та низькою $(r=0,104)$ відповідно. Варіанса специфрічної адаптивної здатності $\left(\sigma_{\text {сасі) }}^{2}\right)$ мала високий зв'язок $(r=0,747)$ з врожайністю в кращих умовах, тоді як з врожайністю в гірших він був від'ємним і низьким $(r=-0,196--0,246)$ (табл. 4).

За параметрами відносної стабільності, варіанси специфічної адаптивної здатності та селекційної цінності генотипу були виділені найкращі популяції: Т./Емерауде, М.g./ЦП-11 і Ж./ ЦП-11 та всі вони істотно перевищували стандарт за врожайністю. Найбільш нестабільними виявилися популяції: LR/ H та Приморка / Сін(с), що мали найгірші показники відносної стабільності, варіанси спе- цифічної адаптивної здатності та селекційної цінності генотипу, а також володіли дестабілізуючим ефектом.

Розглядаючи згенерований біплот, можна провести аналіз впливу року випробування на генотипи та їх реакцію на зміну навколишнього середовища. За результатами GGE біплот-аналізу ми виділили такі найбільш стабільні популяції: G14 - Т./Емерауде, G15 - M.g./ ЦП-11 та G23 - Ж./ ЦП-11, що знаходяться в одній чверті з векторами врожайності за гірших умов (2017 і 2018 роки) та слабкіше реагують на погіршенні умови вирощування. (рис. 1).

Популяції G1 - Унітро, G6 - LR/ H, G7 - Приморка / Сін(c), G13 - (Емерауде /T. ) $)^{2}$ та G18 - A.r. d., що перебувають в третій і четвертій чвертях, утворюючи півколо, показали різке зниження врожайності за гірших умов зволоження.

Популяції G4 - М.g./ П.п. та G5 - Син (c)./Приморка, що знаходяться в першій чверті з вектором врожайності за кращих умов та наближені до його вершини, добре відгукуються на покращення умов зволоження, але володіють середньою (107,10 і 118,60 кг/га відповідно) насіннєвою 
Кореляційні залежності між врожайністю насіння та параметрами адаптивних властивостей зразків люцерни першого року життя за методикою О. В. Кільчевського та ін. (2017-2019рр.)

\begin{tabular}{|c|c|c|c|c|c|c|c|c|c|c|c|}
\hline & Y17/17 & Y18/18 & Y19/19 & Ymean & OACi & $\boldsymbol{\sigma}^{2}(\mathbf{G} \times \mathbf{E}) \mathbf{g i}$ & $\boldsymbol{\sigma}^{2} \mathbf{C A C i}$ & $\mathbf{s}_{\mathrm{gi}}$ & $\mathbf{C L \Gamma i}$ & $\mathbf{K}_{\mathrm{gi}}$ & $\mathrm{I}_{\mathrm{gi}}$ \\
\hline $\mathrm{Y} 17 / 17$ & 1,000 & 0,837 & 0,375 & 0,834 & 0,834 & 0,166 & $-0,246$ & $-0,819$ & 0,935 & $-0,249$ & 0,242 \\
\hline $\mathrm{Y} 18 / 18$ & 0,837 & 1,000 & 0,498 & 0,891 & 0,891 & 0,032 & $-0,196$ & $-0,777$ & 0,955 & $-0,200$ & 0,085 \\
\hline $\mathrm{Y} 19 / 19$ & 0,375 & 0,498 & 1,000 & 0,799 & 0,799 & 0,096 & 0,747 & 0,104 & 0,316 & 0,744 & $-0,214$ \\
\hline $\mathrm{Ymean}$ & 0,834 & 0,891 & 0,799 & 1,000 & 1,000 & 0,119 & 0,212 & $-0,511$ & 0,821 & 0,208 & 0,012 \\
\hline $\mathrm{OACi}$ & 0,834 & 0,891 & 0,799 & 1,000 & 1,000 & 0,119 & 0,212 & $-0,511$ & 0,821 & 0,208 & 0,012 \\
\hline$\sigma^{2}(\mathrm{G} \times \mathrm{E}) \mathrm{gi}$ & 0,166 & 0,032 & 0,096 & 0,119 & 0,119 & 1,000 & 0,156 & $-0,053$ & 0,067 & 0,157 & 0,865 \\
\hline$\sigma^{2} \mathrm{CACi}$ & $-0,246$ & $-0,196$ & 0,747 & 0,212 & 0,212 & 0,156 & 1,000 & 0,719 & $-0,382$ & 1,000 & $-0,244$ \\
\hline $\mathrm{S}_{\mathrm{gi}}$ & $-0,819$ & $-0,777$ & 0,104 & $-0,511$ & $-0,511$ & $-0,053$ & 0,719 & 1,000 & $-0,907$ & 0,721 & $-0,305$ \\
\hline $\mathrm{CL} \Gamma i$ & 0,935 & 0,955 & 0,316 & 0,821 & 0,821 & 0,067 & $-0,382$ & $-0,907$ & 1,000 & $-0,385$ & 0,195 \\
\hline $\mathrm{K}_{\mathrm{gi}}$ & $-0,249$ & $-0,200$ & 0,744 & 0,208 & 0,208 & 0,157 & 1,000 & 0,721 & $-0,385$ & 1,000 & $-0,242$ \\
\hline $\mathrm{I}_{\mathrm{gi}}$ & 0,242 & 0,085 & $-0,214$ & 0,012 & 0,012 & 0,865 & $-0,244$ & $-0,305$ & 0,195 & $-0,242$ & 1,000 \\
\hline
\end{tabular}

продуктивністю, що характеризує їх як пластичні до умов вирощування популяції.

Аналізуючи отримані дані за насіннєвою продуктивністю, параметрами адаптивної здатності та біплот-аналізом, можна розділити досліджувані популяції на три групи: інтенсивного типу, стабільні та адаптовані до різних умов. До найкращих стабільних популяцій відносяться: М.g./ЦП-11 і Ж./ ЦП-11, інтенсивного типу LR/ H, Приморка / Сін(c) та адаптованих до різних умов Син (c)./Приморка і А.-H.d. № 15.

Обговорення. В науковій літературі багато робот присвячено вивченню адаптивних ознак на різних сільськогосподарських культурах з великою кількістю показників. Проте відбір показників адаптивності та встановлення їх параметрів $€$ необхідним тому, що не всі вони здатні характеризувати зразки за адаптивністю.

Дослідження на різних сільськогосподарських культурах показали, що рівень селекційної цінності і гомеостатичності сприяли відбору кращих зразків за адаптивною здатністю. (Ignat'ev \& Regidin, 2019; Habibullin et al., 2020; Lozinskyi, 2018; Postolati, 2016; Demidov et al., 2019). В наших дослідженнях також ці показники мали високу залежність із врожайністю у гірші роки (2017, 2019), і низьку в кращий (2019), що характеризує стійкість популяцій до стресу. За даними дослідників, показники варіанси специфічної адаптивної здатності, відносної стабільності та селекційної цінності генотипу допомагали при відборі кращих зразків за адаптивною здатністю (Kurkova, 2018; Popolzuhin et al. 2018). Це узгоджується з нашими даними та відображає реакцію популяцій до стресу. Отримані показники мали високу залежність з врожайністю в гірші роки $(2017,2019)$, і низьку за кращого року (2019).

В деяких дослідженнях (Ignat'ev \& Regidin, 2019; Lozinskyi, 2018; Postolati, 2016) за коефіцієнтом регресії були розділені зразки різних сільськогосподарських культур на три групи: інтенсивного типу, стабільного та адаптованого до різних умов. Отримані нами дані показали, що коефіцієнт регресії мав від'ємну низьку залежність із врожайністю у гірші роки $(2017,2019)$, і високу за кращого року (2019), що цілком показує реакцію популяцій на умови вирощування.

Показники рівня стресостійкості, коефіцієнта адаптивності, загальної адаптивної здатності та генетичної гнучкості сприяли відбору кращих зразків за адаптивною

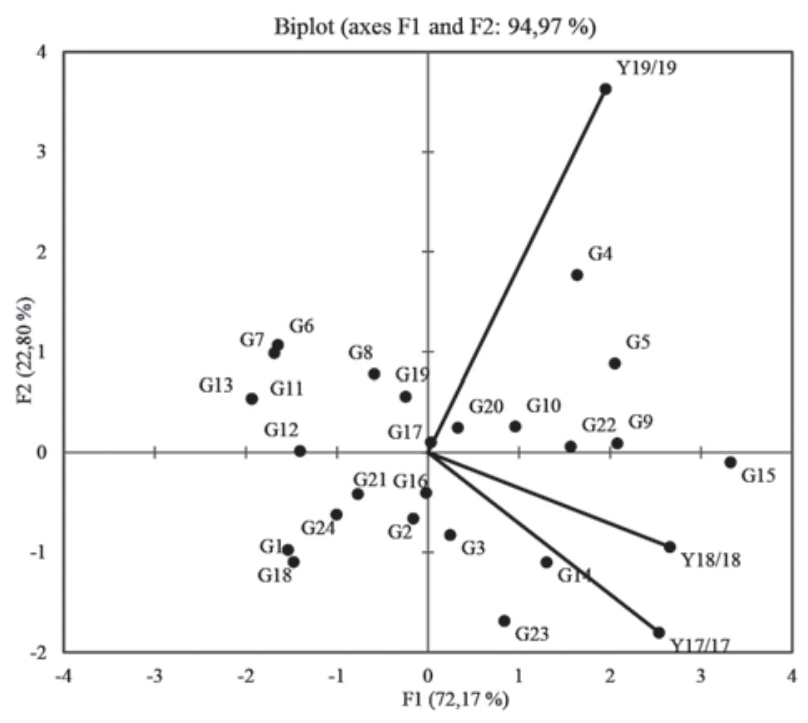

Рис. 1. Генотип-середовищна взаємодія генотипів люцерни і середовищ (роки)(метод біплот-аналіз).

Лініями показані власні вектори провідних факторних навантажень для середовищ: - рік вирощування; - генотип

здатністю на різних сільськогосподарських культурах (Ignat'ev \& Regidin, 2019; Habibullin et al., 2020; Lozinskyi, 2018; Postolati, 2016; Kurkova, 2018; Popov et al., 2019). Отримані нами ці показники не в повній мірі характеризують стійкість популяцій до стресу тому, що мали високу залежність 3 врожайністю як в гірші роки $(2017,2018)$, так і в кращий (2019).

Висновки. Комплексна оцінка досліджуваних популяцій за врожайністю насіння люцерни і параметрами адаптивності з використанням різних методик і біплотаналізу дозволила виділити генотипи, що мають високу потенційну продуктивність і найбільшу адаптивність. До них відносяться генотипи: стабільні M.g. / ЦП-11 і Ж. / ЦП-11, інтенсивного типу - LR/ H, Приморка / Сін(c) та адаптовані до різних умов - Син (с)./Приморка i А.-H.d. № 15, які доцільно використовувати у селекційному процесі люцерни на адаптивність при створенні нових сортів. 


\section{Бібліографбічні посилання:}

1. Abdelguerfi, A., \& Abdelguerfi-Laouar, M. (2002). Forage and pasture species: The uses in Maghreb (Algeria, Morocco, and Tunisia). FAO, Rome, Italy.

2. Aseeva, T. A. \& Zenkina, K. V. (2019). Adaptivnost' sortov jarovoj tritikale v agrojekologicheskih uslovijah srednego Priamur'ja. Rossijskaja sel'skohozjajstvennaja nauka, 1, 9-11. doi: 10.31857/S2500-2627201919-11 (in Russian).

3. Ashraf, M. (2010). Inducing drought tolerance in plants: Recent advances. Biotech. Adv., 28, 169-183.

4. Ayalneh, T., Letta, T. \& Abinasa, M. (2013). Assessment of stability, adaptability and yield performance of bread wheat (Triticum aestivum L.) cultivars in South Eastern Ethiopia. J. Agric. \& Environ. Sci, 13(7), 885-890. doi: 10.5829/idosi. aejaes.2013.13.07.1950.

5. Bajkalova, L. P. \& Serebennikov, Ju. I. (2014). Ocenka adaptivnogo potenciala sortov jachmenja v Kanskoj lesostepi [Assessment of the adaptive potential of barley varieties in the Kansk forest-steppe]. Vestnik KrasGAU, 10, 93-97 (in Russian).

6. Bazalij, V. V. (2004). Principi adaptivnoï selekciï ozimoy pshenyci v zoni Pivdennogo Stepu [Principles of adaptive selection of winter wheat in the Southern Steppe zone]. Ajlant, Herson, 243. (in Ukrainian).

7. Demidov, O. A., Homenko, S. O., Chugunkova, T. V. \& Fedorenko, I. V. (2019). Urozhajnist' ta gomeostatichnist' kolekcijnih zrazkiv pshenici jaroï. Visnik agrarnoï nauki, 9(798), 47-51 (in Ukrainian).

8. Eberhart, S. A. \& Russell, W. A. (1966). Stability parameters for comparing varieties. Crop Science, 6(1), 36-40.

9. Giancarla, V., Madosa, E., Ciulca, S., Ciulca, A., Petolescu, C., \& Bitea, N. (2010). Assessment of drought tolerance in some barley genotypes cultivated in West part of Romania. J. Hortic. For. Biotechnol., 14(3), 114-118.

10. Goncharenko, A. A. (2005). Ob adaptivnosti i jekologicheskoj ustojchivosti sortov zernovyh kul'tur [On the adaptability and ecological sustainability of grain varieties]. Vestnik RASHN, 6, 49-53 (in Russian).

11. Goncharenko, A. A. (2016) a. Sravnitel'naja ocenka adaptivnogo potenciala sortov zernovyh kul'tur i zadachi selekcii [Comparative assessment of the adaptive potential of grain varieties and breeding problems]. Selekcija rastenij: proshloe, nastojashhee i budushhee. Sbornik materialov I Vserossijskoj nauchno-prakticheskoj konferencii s mezhdunarodnym uchastiem, posvjashhjonnoj 140-letiju NIU «BelGU» i 100-letiju so dnja rozhdenija selekcionera, uchenogo i pedagoga, doktora sel'skohozjajstvennyh nauk, professora Shhelokovoj Zoi Ivanovny, 46-48 (in Russian).

12. Goncharenko, A. A. (2016) b. Jekologicheskaja ustojchivost' sortov zernovyh kul'tur i zadachi selekcii [Environmental sustainability of grain varieties and breeding objectives]. Zernovoe hozjajstvo Rossii, 2(44), 31-36 (in Russian).

13. Habibullin, K. N., Ashiev, A. R., \& Skulova, M. V. (2020). Ocenka adaptivnosti I produktivnosti rastenij kollekcii gorokha posevnogo [Assessment of the adaptability and productivity of plants in the collection of sowing peas]. Zernovoe khozyajstvo Rossii. 1(67), 33-36 (in Russian). doi: 10.31367/2079-8725-2020-67-1-33-36

14. Harrison, M. T., Tardieu, F., Dong, Z., Messina, C. D. \& Hammer, G. L. (2014). Characterizing drought stress and trait influence on maize yield under current and future conditions. Glob. Change Biol, 20(3), 867-878. doi: 10.1111/gcb.12381.

15. Hudzenko, V. N. (2019). Statisticheskaja i graficheskaja (GGE biplot) ocenka adaptivnoj sposobnosti i stabil'nosti selekcionnyh linij jachmenja ozimogo [Statistical and graphic (GGE biplot) assessment of adaptive capacity and stability of breeding lines of winter barley]. Vavilovskij zhurnal genetiki i selekcii, 23(1), 110-118 (in Russian). doi: 10.18699/VJ19.469

16. Ignat'ev, S. A., \& Regidin, A. A. (2019). Ocenka parametrov adaptivnosti kollekcionnykh obrazcov ehsparceta [Assessment of the parameters of adaptability of collection specimens of esparcet]. Zernovoe khozyajstvo Rossii, 3(63), 53-58. doi: 10.31367/2079-8725-2019-63-3-53-58 (in Russian).

17. Kil'chevskij, A. V. \& Hotyleva, L. V. (1985). Metod ocenki adaptivnoj sposobnosti i stabil'nosti genotipov, differencirujushhej sposobnosti sredy [Method for assessing the adaptive ability and stability of genotypes, the differentiating ability of the environment]. Soobshhenie I. Obosnovanie metoda. Genetika, XXI(9), 1481-1489 (in Russian).

18. Kil'chevskij, A. V. \& Hotyleva, L. V. (2008). Geneticheskie osnovy selekcii rastenij [Genetic bases of plant selection]. $\checkmark 4$ t. T. 1. Obshhaja genetika rastenij. Belorus. nauka, Minsk, 551 (in Russian).

19. Kordjum, E. L. \& Dubina, D. V. (2015). Plastichnist' ontogenezu sudinnih roslin :molekuljarni, klitinni, populjacijni ta cenotichni aspekti. Visn.NAN Ukraïni, 7, 32-36. http://nbuv.gov.ua/UJRN/vnanu_2015_7_7 (in Ukrainian).

20. Kurkova, I. V., \& Fokin, S. A. (2018). Ocenka adaptivnoj sposobnosti i ekhōlogicheskoj plastichnosti sortov i sortoobrazcov yarovogo yachmenya amurskoj selekcii [Assessment of the adaptive capacity and ecological plasticity of verieties and varieties of spring barley of the Amur selection]. Vestnik KraSGAU, 2, 16-21 (in Russian).

21. Latrach, L., Farissi, M., Mohammed, M., Makoudi, B., Bouizgaren, A. \& Ghoulam, C. (2014). Growth and nodulation of alfalfa-rhizobia symbiosis under salinity: electrolyte leakage, stomata conductance, and chlorophyll fluorescence. Turkish Journal of Agriculture and Forestry, 38, 320-326. doi:10.3906/tar-1305-52.

22. Litun, P. P. (1980). Vzaimodejstvie genotip-sreda v geneticheskih issledovanijah i sposoby ego izuchenija [Genotypeenvironment interaction in genetic research and methods of its study]. Problemy otbora i ocenki selekcionnogo materiala. K, Naukova dumka, 63-93 (in Russian).

23. Lozinskyi, M. V. (2018). Adaptyvnist selektsiinykh nomeriv pshenytsi ozymoi, otrymanykh vid skhreshchuvannia riznykh ekotypiv za kilkistiu koloskiv v holovnomu kolosi [Adaptability of selection numbers of winter wheat, taken from different types of growing varieties for a number of spikes at the head spike]. Ahrobiolohiia, 1, 233-243 (in Ukrainian).

24. Mel'nik, A. V., Roman'ko, Ju. O. \& Roman'ko, A. Ju. (2020). Adaptivnij potencial i stresostijkist' suchasnih sortiv soyi [Adaptive potential and stress resistance of modern soybean varieties]. Tavrijs'kij naukovij visnik, 113, 85-91. doi: 10.32851 /2226-0099.2020.113.12 (in Ukrainian).

25. Orljuk, A. P. \& Goncharova, K. V. (2002). Adaptivnij i produktivnij potenciali pshenici [Wheat adaptive and productive potential]. Ajlant, Herson, 275 (in Russian).

26. Popolzuhin, P. V., Vasilevskij, V. D., Gajdar, A. A., Kuz'mina, E. S. \& Parshutkin, Ju. Ju. (2018). Adaptivnyj potenial sortov mjagkoj jarovoj pshenicy raznyh grupp spelosti v juzhnoj lesostepi Zapadnoj Sibiri. Sostojanie i perspektivy nauchnogo 
obespechenijaAPK Sibiri: Sbornik nauchnyh statej, posvjashhennyj 190-letiju opytnogo dela v Sibiri,100-letiju sel'skohozjajstvennoj nauki v Omskom Priirtysh'e i 85-letiju obrazovanija Sibirskogo NII sel'skogo hazjajstva, 201-204. (in Russian).

27. Popov, S. I., Leonov, O. Yu., Popova, K. M., \& Avramenko, S. V. (2019). Ecological plasticity of winter wheat varieties depending on root nitrogen nutrition in the eastern Forest-Steppe of Ukraine. Plant Varieties Studying and Protection, 15(3), 296-302 (in Ukrainian). doi: 10.21498/2518-1017.15.3.2019.181087

28. Postolati, A. A., Sergej, T. P., \& Pleshka, A. V. (2016). Uroven' adaptivnoj sposobnosti i stabil'nosti razlichnykh genotipov Triticum aestivum L. v usloviyakh Bel'skoj stepi [The level of adaptive ability and resistance of different genotypes of Triticum aestivum L. in the conditions of the Belskaya steppe]. Ştiinţa agricolă, 1, 26-30 (in Russian).

29. Surin, N. A., Zobova, N. V., Ljahova, N. E., Neshumaeva, N. V., Plehanova, L. V., Chuslin, A. A., Onufrienok, T. V., Gerasimov, S. A. \& Lipshin, A. G. (2016). Istochniki cennyh priznakov v selekcii jachmenja na adaptivnost' [Sources of valuable traits in barley breeding for adaptability]. Dostizhenija nauki i tehniki APK, 30(6), 36-40 (in Russian).

30. Tyshchenko, A. V., Tyshchenko, O. D., \& Liuta, Yu. O. (2021). Otsinka henotypiv liutserny za nasinnievoiu produktyvnistiu na posukhostiikist [Assessment of alfalfa genotypes for their productivity on dryness]. Tavriiskyi naukovyi visnyk, 120. 155-168 (in Ukrainian). doi: 10.32851/2226-0099.2021.120.21

31. Tyshchenko, A. V., Tyshchenko, O. D., Liuta, Yu. O., \& Piliarska, O. O. (2021). Adaptyvna zdatnist - vazhlyva oznaka $\checkmark$ selektsii Roslyn [Adaptive ability is an important feature in plant breeding]. Zroshuvane zemlerobstvo: mizhvidomchyi tematychnyi naukovyi zbirnyk. VD «Helvetyka», Kherson, 75, 101-109 (in Ukrainian).

32. Vasconcelos, E. S., Barioni Júnior, W., Cruz, C. D., Ferreira, R. de P., Rassini, J. B. \& Vilela, D. (2008). Alfalfa genotype selection for adaptability and stability of dry matter production. Acta Sci. Agron. 30, 339-343. doi: 10.4025/ actasciagron.v30i3.3511.

33. Wang, Z., Ke, Q, Kim, M. D., Kim, S. H., Ji, C. Y., \& Jeong, J. C. (2015). Transgenic Alfalfa Plants Expressing the Sweetpotato Orange Gene Exhibit Enhanced Abiotic Stress Tolerance. PLoS ONE, 10(5), e0126050. doi: 10.1371/journal. pone. 0126050

34. Zajceva, I. O. (2015). Analiz fenoritmiki ta adaptivnih vlastivostej kleniv v umovah introdukciï u Stepovomu Pridniprov'y [Analysis of phenorhythmics and adaptive properties of maples in the conditions of introduction in the Steppe Dnieper]. Visnyk Dnipropetrovs'kogo derzhavnogo agrarno-ekonomichnogo universitetu. 6-12 (in Ukrainian).

35. Zhuchenko, A. A. (2009). Adaptivnoe rastenievodstvo jekologo-geneticheskoe osnovy. Teorija i praktika [Adaptive plant growing ecological-genetic basis. Theory and practice]. V 3-h t. Agrorus, M., 2, 1104 (in Russian).

Vozhegova R. A., Doctor (Agricultural Sciences), Professor, Academician of NAAS of Ukraine, Director, Institute of Irrigated Agriculture, Kherson, Ukraine

Tyshchenko A. V., PhD (Agricultural Sciences), Senior Researcher, Institute of Irrigated Agriculture, Kherson, Ukraine

Tyshchenko O. D., PhD (Agricultural Sciences), Senior Researcher, Institute of Irrigated Agriculture, Kherson, Ukraine

Dimov O. M., PhD (Agricultural Sciences), Senior Researcher, Institute of Irrigated Agriculture, Kherson, Ukraine

Lyuta Yu.O., PhD (Agricultural Sciences), Associate Professor SHEI Priazovsky State Technical University, Mariupol, Ukraine

Features of manifestation of adaptive traits in breeding populations of alfalfa in seed production

Adaptive traits in alfalfa populations have been studied: plasticity, stability, genetic flexibility, general and specific adaptability in seed use, promising material for its further use in the selection process has been identified. Field, statistical. The research was conducted at the Institute of Irrigated Agriculture of NAAS of Ukraine during 2017-2020 pp. 24 alfalfa populations were studied. Environmental condition indices (lj) were used to assess growing conditions. The most favorable conditions for the formation of seed productivity were in 2019 ( $\mathrm{lj}=+123.87)$, in 2017 they were unfavorable $(\mathrm{lj}=-24.94)$, in 2018 - conditions were very unfavorable $(\mathrm{lj}=-\mathrm{9}$-9.93). Seed yield in alfalfa genotypes ranged from 169.57 to $243.10 \mathrm{~kg} / \mathrm{ha}$. There was a high positive relationship between seed yield in alfalfa populations $(r=0.768-0.882)$ with the index of genetic flexibility (Gf), total adaptive capacity (OACi) $(r=0.799-0.891)$ and adaptability coefficient $(K A)(r=0.799-0.891)$. On the base of data analyze of seed productivity of alfalfa population for the first year its populations can be divided into three groups: intensive, stable and adapted types on the parameters of adaptive capacity and biplot analysis. The best stable populations were: $M g$ / CP-11 and J. / CP-11, intensive type - LR / H, Primorka / Sin (s) and adapted to different conditions - Sin (s) / Primorka and A.-N .d. № 15. Comprehensive assessment of populations on alfalfa seed yield and adaptability parameters using different methods and biplots analysis allowed to identify genotypes with high potential productivity and the greatest adaptability. These include genotypes: stable Mg / CP-11 and J. / CP-11, intensive type $L R / H$, Primorka / Sin (s) and adapted to different conditions - Sin (s) ./ Primorka and A.-N.d. № 15, which should be used in the selection process of alfalfa for adaptability in the creation of new varieties.

Key words: genotype, seed productivity, parameters of adaptive traits, correlation, biplot analysis. 